\title{
A PROVA DO DANO MORAL NO PROCESSO DO TRABALHO: O ENTENDIMENTO DOS TRIBUNAIS SOBRE A POSSIBILIDADE DA UTILIZAÇÃ̃O DA GRAVAÇÃO E AS NOVAS TECNOLOGIAS DE COMUNICAÇÃ̃ ${ }^{1}$
}

Miriam Olivia Knopik Ferraz

Mestranda em Direito pela PUCPR (Bolsista CAPES). Secretária Executiva da Revista de Direito Econômico e Socioambiental do PPGD da PUCPR. Pós-graduanda em Direito Constitucional pela Academia Brasileira de Direito Constitucional. Secretária Executiva da Revista de Direito Econômico e Socioambiental da PUCPR. Membro do Núcleo de Estudos Avançados em Direito do Trabalho e Socioeconômico, Núcleo de Pesquisas em Políticas Públicas e Desenvolvimento Humano, Núcleo de Estudos de Pesquisas em Tributação, Complexidade e Desenvolvimento. Membro da Comissão de Igualdade Racial da OAB/PR. Advogada. m.okf@ hotmail.com

\section{Marco Antônio César Villatore}

Pós-Doutor pela Universitá degli Studi di Roma II, Doutor em Diritto del Lavoro, Sindacale e della Previdenza Sociale - Università degli Studi di Roma, La Sapienza\&quot, revalidado pela Universidade Federal de Santa Catarina. Mestre em Direito pela Pontifícia Universidade Católica de São Paulo Professor Titular do Programa de Pós-Graduação em Direito na Pontifícia Universidade Católica do Paraná (PPGD/PUCPR). Coordenador do Curso de Especialização em Direito do Trabalho da Pontifícia Universidade Católica do Paraná. Presidente do Instituto brasileiro de Ciências Jurídicas e Sociais (IBCJS). Professor Adjunto III da Universidade Federal de Santa Catarina. Membro do Centro de Letras do Paraná. Acadêmico da cadeira número 73 da Academia brasileira de Direito do Trabalho. Professor do UNINTER. Diretor Cultural e Ex-Diretor Administrativo e ExConselheiro Geral do Instituto dos Advogados do Paraná. Advogado.

prof.villatore@gmail.com

RESUMO: O presente trabalho tem por objetivo analisar algumas formas probatórias quando se trata de matéria de dano moral no processo do trabalho, observando as mudanças realizadas pela reforma trabalhista Lei $\mathrm{n}^{\circ} 13.567 / 2017$. Para tanto, estuda-se a doutrina sobre a temática e adentra-se na pesquisa de jurisprudência. Foram realizadas quatro metodologias diferentes para estudar como os tribunais tratam a temática, variando entre quantitativas, qualitativas e por

\footnotetext{
1 Artigo desenvolvido com base nos estudos da disciplina: "A atividade econômica do empregador e o Direito da personalidade”. Ministrada pelo Prof. Marco Antônio Cesar Villatore e no Núcleo de Estudos Avançados de Direito do Trabalho e Socioeconômico da Pontifícia Universidade Católica do Paraná.
} 
A prova do dano moral no processo do trabalho: o entendimento dos tribunais sobre a possibilidade da utilização da gravação e as novas tecnologias de comunicação

amostragem. Em um primeiro momento analisa-se como os tribunais do trabalho de Minas Gerais, Pará e Amapá, Santa Catarina, Piauí e Mato Grosso, em conjunto analisados como um representante de cada região do país, entendem a utilização da gravação como prova do dano moral. Posteriormente se realiza uma pesquisa ampla das decisões do Tribunal Superior do Trabalho e uma pesquisa dos principais precedentes do Supremo Tribunal Federal. Para uma análise alinhada as novas tecnologias, estuda-se no Tribunal Regional do Trabalho do Paraná a possibilidade da utilização da gravação, "whatsapp", "e-mail", "facebook" como formas probatórias em matéria de dano extrapatrimonial ou moral. Por fim, por meio desse estudo jurisprudencial, traça-se os obstáculos e discussões quanto a confiabilidade das provas realizadas por meios tecnológicos, e elenca-se possíveis formas de superação.

PALAVRAS-CHAVE: Prova do Dano Moral. Tribunais. Gravação. Novas tecnologias de comunicação. Reforma Trabalhista.

\title{
The proof of moral damage in the labor process: the understanding of the courts on the possibility of the use of recording and the new communication technologies
}

\begin{abstract}
The present work by the survey probabilistic matrices for moral process of moral process in the work, observing the changes works by the labor reform Law $n^{\circ} 13.567$ / 2017 . For this, a doctrine on the subject is studied and it enters in the research of jurisprudence. The four methodologies are different to study how courts deal with the issue, varying between quantitative, qualitative and by sampling. Firstly, we analyze how the labor courts of Minas Gerais, Pará and Amapá, Santa Catarina, Piauí and Mato Grosso, together as a representative of each region of the country, can be understood as an example. The articles of this main question of the Federal Supreme Court. For an analysis aligned as new technologies, it is studied in the Regional Labor Court of Paraná a possibility of using whatsapp, e-mail and facebook as the probabilities of off-balance or moral damage. Finally, through jurisprudential teaching, the trajectory and ways of overcoming.
\end{abstract}

KEYWORDS: Proof of Moral Damage. Courts. Recording. New communication technologies. Labor Reform.

\section{INTRODUÇÃO}

A prova no Dano moral por si só é uma prova complexa de ser realizada, os próprios requisitos desse instituto podem ser diversas vezes maleados em situações determinadas. Com a crescente expansão das demandas sobre a matéria e as alterações trazidas pela reforma trabalhista cabe o estudo de um instituto que muitas vezes é esquecido: a prova. Há um tempo a possibilidade de gravação vem alcançando os tribunais brasileiros e estes vêm se deparando com este paradigma em contraponto a inviolabilidade das ligações telefônicas. Ainda, um novo desafio encontra o Judiciário, as novas tecnologias de comunicação como "e-mail", "whatsapp", "facebook", e junto com todas as possibilidades probatória em formato tecnológico caminham as possibilidades de fraude, algo que não está sendo visto pelos tribunais.

Este estudo se subdivide em cinco tópicos: primeiramente traça os parâmetros da prova em matéria de dano moral no Processo do Trabalho e as inovações da Reforma Trabalhista; Após adentra-se nas pesquisas de jurisprudência sobre a possibilidade de utilização de gravação como prova de dano moral, a primeira pesquisa foi realizada em tribunais das cinco regiões brasileiras: TRT 3 - Minas Gerais, TRT 8 - Pará e Amapá, TRT 12- Santa Catarina, TRT 22 Piauí e TRT 23 - Mato Grosso; a segunda no entendimento do Tribunal Superior do Trabalho e do Supremo Tribunal Federal; e a última tratou da possibilidade da utilização da gravação e 
novas tecnologias de comunicação no Tribunal Regional do Trabalho da 9a Região - Paraná, sendo portanto uma pesquisa mais ampla que converge para o último ponto. No último ponto do estudo pontua-se os obstáculos à validação e confiabilidade das provas realizadas por meios tecnológicos e possíveis formas de superação.

O presente estudo tem por objetivo demonstrar três principais vertentes da prova: a possível ampliação probatória exigível pela reforma trabalhista; a situação atual nos tribunais das gravações como prova e a fragilidade das provas realizadas por meios eletrônicos/virtuais.

\section{A prova do dano moral no Processo do Trabalho e as INOVAÇÕES DA REFORMA TRABALHISTA LEI № 13.467/2017}

Há muito se desenvolve tanto na doutrina civilista como trabalhista a temática do Dano Moral e essencialmente este diferencia-se do dano patrimonial, pois decorre da violação dos direitos da personalidade atingindo então, interesse que não possui relação com expressão econômica, ou seja, em sua expressão mais pura: o dano extrapatrimonial. (DALLEGRAVE NETO, 2007). A maioria dos autores ao conceituar esse dano, realiza dessa forma negativa: o dano moral é o dano que não é patrimonial. (FARIAS, 2015, p. 247; DINIZ, 1998, p. 5; SAVATIER apud SANTINI, 1997, p. 42; RODRIGUES, 2002, p. 30.) Há ainda autores que traçam a diferença entre o Dano moral e o Dano extrapatrimonial, sendo este a lesão a todo o interesse existencial, como um gênero e as espécies seriam o dano moral, estético e existencial. (FARIAS, 2015, p. 247) Cabe a ressalva de que a maioria dos autores compreende a possibilidade de dano moral decorrente de acidente ou doença do trabalho (OLIVEIRA, 2011, p. 326), e a doutrina se divide quanto a possibilidade de dano moral em decorrência de atraso ou ausência de pagamento de verbas (OLIVEIRA, 2011, p. 649) (parte entende ser este um direito exclusivamente material). A indenização possui como objetivo não a restituição ao status quo ante, mas sim, pelo dano moral tida como uma compensação. (CASILLO, 1994, p. 84) Nesse trabalho utiliza-se predominantemente a terminologia "dano moral", pois esta é consagrada pela doutrina e ainda é amplamente utilizada pela jurisprudência, além de ser o termo que se utilizou nas pesquisas jurisprudencial.

Ademais, o Dano Moral, segundo o Conselho Nacional de Justiça (CNJ, 2017), é o segundo assunto mais demandado na Justiça do Trabalho (representando 1,64\% dos assuntos demandados), ficando atrás apenas de pedidos relacionados a rescisão de trabalho e verbas rescisórias (representando 11, 51\%). Originalmente o dano moral no Brasil ${ }^{2}$, mesmo na esfera trabalhista, possuía como fundamento jurídico a prescrição geral da constituição ${ }^{3}$ e a previsão nos dispositivos do Código $\mathrm{Civil}^{4}$ que permite a responsabilidade decorrente da prática do ato ilícito e a necessidade da reparação em decorrência desse dano de forma independente da culpa.

2 Sobre o tema consulte: FERRAZ; MIKOS, 2018.

3 O dever de indenizar o empregado pelos danos materiais e morais por ele sofridos em patamar constitucional irá decorrer das seguintes prescrições: 1) A dignidade da pessoa humana e os valores sociais do trabalho (art. $5^{\circ}$, III e IV); 2) Proibição de qualquer forma de discriminação (art. $3^{\circ}$, IV, e art.7 $7^{\circ}, \mathrm{XXX}, \mathrm{XXXI}$ e XXXII); 3) Direito de resposta, proporcional ao agravo, além da indenização por dano material, moral e à imagem (art. $\left.5^{\circ}, \mathrm{V}\right)$; 4) Inviolabilidade da intimidade, da vida privada, da honra e da imagem das pessoas, assegurando o direito a indenização pelo dano material e moral decorrente de sua violação $\left(\operatorname{art} .5^{\circ}, X\right)$; 5) Proteção da saúde e da integridade física do trabalhador, assegurando o direito a indenização quando o empregador incorrer em dolo ou culpa (art. $7^{\circ}$ XXII, XXVIII).

4 Conforme disposto no Código Civil, comete ato ilícito aquele que por ação ou omissão voluntária, negligência ou imprudência, aquele que violar ou causar dano a outro, ainda que somente moral (art. 186) e ainda, há a obrigação de reparação independente de culpa em casos específicos de lei ou, quando a atividade normalmente desenvolvida implica risco para os direitos de outro (art. 927, caput, §único). 
A prova do dano moral no processo do trabalho: o entendimento dos tribunais sobre a possibilidade da utilização da gravação e as novas tecnologias de comunicação

A CLT permanecia dispondo apenas do dano patrimonial, então, quando diante de um dano moral o jurista deveria observar a legislação civil, uma vez os direitos de personalidade encontram-se inevitavelmente em causa em todo e qualquer contrato de trabalho. (MALLET, 2004, p. 1309). Efetivamente a temática da prova no dano moral é pouco tratada e pouco desenvolvida em matéria de Direito do Trabalho.

Primeiramente ressalta-se que a prova é normalmente vista como elemento essencial para a composição da decisão do magistrado, ao seu convencimento e convicção (CHIOVENDA, 2002, p. 109): "é um conjunto de atividades de verificação e demonstração, mediante os quais se procura chegar à verdade quanto aos fatos relevantes para o julgamento". (DINAMARCO, 2010, p.42)

As divergências doutrinárias quanto a prova do dano moral podem ser sintetizadas em três tópicos (VALLER, 1995; PAMPLONA FILHO, 1998): i. É necessário a idêntica atividade probatória utilizada para a prova do dano material; ii. A prova in re ipsa, ou seja, o dano moral se prova por si mesmo; iii. A satisfação da prova se dá pelas presunções hominis ou presunções realizadas pela atividade de consciência do julgador.

A primeira teoria é descartada por parte da doutrina, ao afirmar que não é possível a exigência de prova direta para o dano moral, pois apenas atestados médicos e depoimentos não podem demonstrar a dor e o sofrimento. (VALLER, 1995, p. 309) A segunda também apresenta posições contrárias, uma vez que não seria admissível as presunções absolutas, sem a possibilidade de apresentação de prova em contrário, pois representariam cerceamento do "direito do réu de tentar produzir prova da inexistência do dano alegado". (PAMPLONA FILHO, 1998, p.117)

Dessa forma, resta como sobrevivente a possibilidade da presunção hominisie da livre consciência do julgador de acordo com as provas apresentadas. Neste caso, a parte que afirma o dano moral deverá alegar os indícios para a configuração da presunção e ao réu cabe apresentar elementos que impeçam essa presunção. (PAMPLONA FILHO, 1998, p.117) Além disso, Carlos Alberto Bittar ressalta que há alguns fatos "sabidamente hábeis a produzir danos de ordem moral, que à sensibilidade do juiz logo se evidenciam" (BITTAR, 1993, p.204), é o caso do acidente de trabalho. Em consonância a essa doutrina temse a jurisprudência do Tribunal Superior do Trabalho, a qual destaca-se o precedente do trabalhador que sofreu acidente do trabalho na Bunge Fertilizantes, em 1994 (BRASIL, Tribunal Superior do Trabalho. Recurso de Revista $n^{\circ}$ 1060-91.2010.5.02.0255), o qual causou-lhe traumatismo crânio-encefálico com necessidade de reconstrução do pavilhão auditivo.

$\mathrm{Na}$ época o relator Mauricio Godinho Delgado, analisou o caso sob três passos para a materialização do dano moral: 1. Fato ou o próprio dano, no caso o acidente, sendo possível a configuração somente em decorrência disto; 2 . Nexo causal, que no caso foi evidenciado pelas condições de trabalho e pelo próprio acidente; 3. Culpa empresarial. O relator ressalta que a culpa não deve ser presumida em diversos casos de dano moral, mas "tratando-se de doença ocupacional, profissional ou de acidente do trabalho, essa culpa é presumida", uma vez que o empregador tem o controle e a direção sobre a estrutura, a dinâmica, a gestão e a operação do estabelecimento em que ocorreu o malefício. Assim, ressalta-se também, a própria responsabilização objetiva do empregador, modalidade comum na seara trabalhista que inova muito da tradição civilista. 
Como se observa, é possível a flexibilização dos critérios rígidos da responsabilidade civil, a depender do caso concreto a que se depara. A Lei no 13.467/2017, intitulada Reforma Trabalhista, trouxe significativas mudanças para a temática e trouxe expressamente para a CLT disposições sobre o dano moral. ${ }^{5}$ Analisa-se as alterações que efetivamente ensejam também consequências a sistemática probatória.

$\mathrm{O}$ art. 223-A estipula que os danos de natureza extrapatrimonial são apenas os decorrentes do capítulo "Títtulo II-A - do dano extrapatrimonial", realizando assim, de antemão, uma restrição à liberdade interpretativa do juiz, da doutrina, das partes, do ministério público etc. Como consequência, a prova estará adstrita as "possibilidades de dano", e como a legislação restringiu essas possibilidades (apresentando um rol taxativo) a prova estará restrita a esses tópicos.

A diferença de terminologia de "dano moral" e "dano extrapatrimonial" era restrita a debates teóricos, mas que tomou corpo e foi reacendido com a reforma trabalhista Lei no. 13.467/2017. O legislador pontuou no art. 223-B que o dano extrapatrimonial é compreendido como todo àquele que resultar da ofensa à esfera moral ou existencial. Muitos autores pontuam que o dano moral integra a esfera existencial ${ }^{6}$ do ser humano, e além disso, tal dispositivo permitiria que não se enquadrasse como dano extrapatrimonial o dano estético (a pesar de posteriormente tratar da imagem, uma de suas facetas). (SOUZA JÚNIOR; SOUZA; MARANHÃO; AZEVEDO NETO, 2018)

Entretanto, a este trabalho posiciona-se no sentido de que a reforma trouxe um avanço para a distinção teórica, não se separa mais em várias categorias como dano moral, estético, existencial e patrimonial, agora há apenas duas: o dano patrimonial e o dano extrapatrimonial (e este congloba todas as relações não patrimoniais, ou seja, o moral, estético, existencial e etc.).

Ademais, apesar de acrescentar como sujeito a pessoa jurídica (Art. 223-B), não especificou a possibilidade do dano coletivo que possui caráter metaindividual, este está amparado pela CRFB/1988 art. 5ㅇ, X; Lei no 7.347/1985, art. 1o; Lei no 8.078/1990, art. 6o VI. Além disso, traz expressamente a restrição da reparação/indenização aos "titulares exclusivas do direito à reparação". Nesse sentido causa dúvidas sobre o possível dano em ricochete, e assim, a comprovação no processo desse dano, possivelmente não será aceita, pois essa modalidade de dano não será aceita.

Os art. 223-C e 223-D trazem especificamente o que pode ser objeto de dano moral, sendo este um rol taxativo se aplicado à risca o disposto no art. 223-A, e trazem a subdivisão dos danos à pessoa física e a pessoa jurídica: a. à pessoa física: a honra, a imagem, a intimidade, a liberdade de ação, a autoestima, a sexualidade, a saúde, o lazer e a integridade física; a pessoa jurídica: a imagem, a marca, o nome, o segredo empresarial e o sigilo da correspondência.

No art. 223-E há a disposição de quais atores teriam a responsabilidade pelo dano: "todos que tenham colaborado para a ofensa ao bem jurídico tutelado, na proporção da ação ou omissão".

$\mathrm{O}$ art. 223-F trata da possibilidade da cumulação da reparação por danos extrapatrimoniais os danos patrimoniais quando decorrentes do mesmo ato lesivo. Segundo o §1 @ há a obrigação do julgador discriminar de forma relacionada as verbas requeridas aos danos. No $§ 2$ ㅇo

5 Sobre a temática consulte: FERRAZ; MIKOS, 2018.

6 O dano existencial teve origem no direito italiano, sobre o tema consulte: MARANHÃO, 2015, p. 307-318. 
A prova do dano moral no processo do trabalho: o entendimento dos tribunais sobre a possibilidade da utilização da gravação e as novas tecnologias de comunicação

referido artigo há a previsão da composição dos perdas e danos compreendidas pelos lucros cessantes e os danos emergentes, o que não interfere na avaliação do dano extrapatrimonial.

O artigo que traz maiores discussões é o art.223-G que estipula o que o juiz deverá considerar para avaliar o dano moral, com destaque para os pontos: a natureza do bem jurídico tutelado; a intensidade do sofrimento ou da humilhação; a possibilidade de superação física ou psicológica; os reflexos pessoais e sociais da ação ou omissão; a extensão e duração dos efeitos da ofensa; o grau de dolo ou culpa; a retratação espontânea; o esforço efetivo para minimizar a ofensa; o perdão, tácito ou expresso; a situação social e econômica das partes envolvidas e o grau de publicidade da ofensa.

Assim, seguindo a linha da doutrina o juiz terá um "passo-a-passo" para a valoração do dano moral.

O §1 o trata da fase pós- definição do dano moral e sua relativa importância, ele traz em seu escopo a vinculação da natureza da lesão ao último salário contratual do ofendido.

Ofensa de natureza leve será remunerada em até três vezes o último salário contratual do ofendido; ofensa de natureza média será remunerada em até cinco vezes o último salário contratual do ofendido; ofensa de natureza grave será remunerado em até vinte vezes o último salário contratual do ofendido; ofensa de natureza gravíssima até cinquenta vezes o último salário do ofendido. ${ }^{7}$

Segundo o §2으, no caso de ofensa à pessoa jurídica a indenização será fixada nos mes-

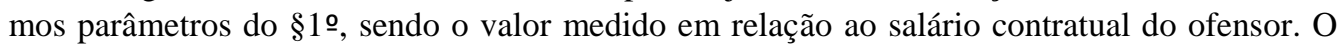
§3o o juízo poderá elevar em dobro a indenização no caso de reincidência entre partes idêntica.

Ressalta-se por fim, o instituto do ônus da prova. Antes da reforma trabalhista o ônus da prova era atribuído a quem alegava a existência de um fato, ou seja, a prova das alegações incumbe à parte que as faz (CLT, art. 818). Entretanto, devido a dificuldade probatória na seara trabalhista, principalmente devido ao fato de o trabalhador não deter os documentos necessários ou ainda, pela extrema dificuldade de se provar um dano extrapatrimonial (ASSIS, 1997, p. 03-05), os tribunais começaram a reavaliar a distribuição do ônus da prova (FELICIANO, 2008), assim realinhou-se o ônus da prova: o ônus do empregador provar fato impeditivo, modificativo ou extintivo da equiparação salarial (TST, Súmula 6, VIII) e ônus do empregado a prova dos fatos constitutivos de seu direito. Com a reforma trabalhista, tal disposição foi transpassada para a letra de lei, incorporando, nos exatos termos o art. 818 da CLT.

Ressalta-se que a Reforma inovou ao prever que em casos específicos (por previsão legal ou pela dificuldade concreta) em que se vislumbre a impossibilidade ou à excessiva dificuldade de cumprir com o ônus da prova, poderá o juízo atribuir o ônus da prova de modo diverso.

Efetivamente a alteração mais controversa dispositivo que pode resultar em mudanças significativas para a prova está principalmente no disposto pelo art. 223-G que estipula o que o juiz deverá considerar para avaliar o dano moral, como por exemplo a intensidade do sofrimento ou da humilhação, a possibilidade de superação física ou psicológica, os reflexos pessoais e sociais da ação ou omissão, a extensão e duração dos efeitos da ofensa e etc. Não vem sendo debatido a quem caberá o ônus de provar todas essa situações, ou ainda, se isto restará apenas à convicção do juiz e sua análise dos fatos ocorridos.

\footnotetext{
7 A Medida provisória no 808/2017 substituiu as expressões "último salário do ofendido" para "o teto da previdência social". Entretanto, no momento da elaboração desse artigo ela não encontra-se mais em vigência.
} 
Ademais, como visto, a reforma trabalhista trouxe diversas alterações a temática substanciais a direitos do trabalho, entretanto, nada inovou quanto a mecanismos e formas de limitar a fragilidade de normas, principalmente quando diversos meios eletrônicos como e-mail, facebook, whatsapp e gravações são utilizados como meio de prova. Dessa forma, observa-se o contraste formado: amplia-se a normativa relativa ao dano extrapatrimonial e por outro lado, pouco se discute quanto a fragilidade e novas formulações de prova. Uma realidade que vem tomando força há muito tempo o que clama por um debate mais aprofundado e sério.

Ao presente estudo então, realiza-se cinco mapeamentos de jurisprudência: quatro voltados a possibilidade da "gravação" como meio de prova para dano moral, destas duas análises quantitativas e duas qualitativas; A hipótese inicial é de que não há diferenças regionais, sempre são aceitas as gravações como prova de dano moral.

Um mapeamento voltado realizado de forma qualitativa para demonstrar o comportamento dos tribunais diante de provas eletrônicas como e-mail, facebook, whatsapp, mensagens e etc. As metodologias e parâmetros serão demonstrados em cada capítulo.

\section{A POSSIBILIDADE DE GRAVAÇÃO: O ENTENDIMENTO DOS TRIBUNAIS DAS CINCO REGIÕES BRASILEIRAS: TRT 3 - MINAS Gerais, TrT 8 - 'PArá e Amapá, TRT 12-SAnta Catarina, TRT 22 - Piauí e TRT 23 - MAto Grosso}

A primeira pesquisa jurisprudencial realizada foi feita com o objetivo de traçar como os tribunais entendem a possibilidade da gravação como meio de prova no dano moral. Nesse extrato da pesquisa buscou-se mapear as cinco regiões do Brasil: SUL no TRT 12 Santa Catarina; Sudeste no TRT 3 Minas Gerais; Centro- Oeste no TRT 23 Mato Grosso; Nordeste TRT 22 Piauí; e Norte TRT8 Pará e Amapá. Não foram escolhidos os estados que mais demandam ações, pois não seria possível realizar a análise regional a que se pretende, uma vez que só no estado de são Paulo foram encontradas 4 mil decisões.

Para tanto, foi pesquisado o termo "gravação" no sítio eletrônico de cada tribunal, o termo necessariamente deveria estar presente na ementa do acórdão e, com o objetivo de mapear as decisões mais recentes e estipular um marco temporal, a pesquisa foi restrita a 01.01.2017 a 23.04.2018, exceto Santa Cataria que buscou-se de 01.01.2013 a 23.04.2018. A hipótese inicial era de que não haveriam diferenças de regionalidades e todos os tribunais aceitariam a gravação como meio de prova para o dano moral. Foram encontrados 52 resultados, distribuídos na seguinte forma: 10 decisões no TRT 12 Santa Catarina; 7 decisões no TRT 3 Minas Gerais; 4 decisões no TRT 23 Mato Grosso; 1 decisão no TRT 22 Piauí; 30 decisões no TRT 8 Pará e Amapá. Ademais, passa-se a análise de cada tribunal.

Por motivos de limitação de espaço todas as decisões selecionadas foram organizadas no Anexo 1. 
A prova do dano moral no processo do trabalho: o entendimento dos tribunais sobre a possibilidade da utilização da gravação e as novas tecnologias de comunicação

\subsection{TRT 12 Santa Catarina}

No TRT 12 de Santa Catarina foram encontradas 10 decisões $^{8}$ sob o marco temporal 01.01.2013 a 23.04.2018, optou-se por ampliar o marco temporal para colher, pois não foram encontradas decisões entre 2017 e 2018 . Ressalta-se, ainda assim, que o principal problema de pesquisa foram os poucos resultados. Os resultados foram sintetizados no gráfico 1 .

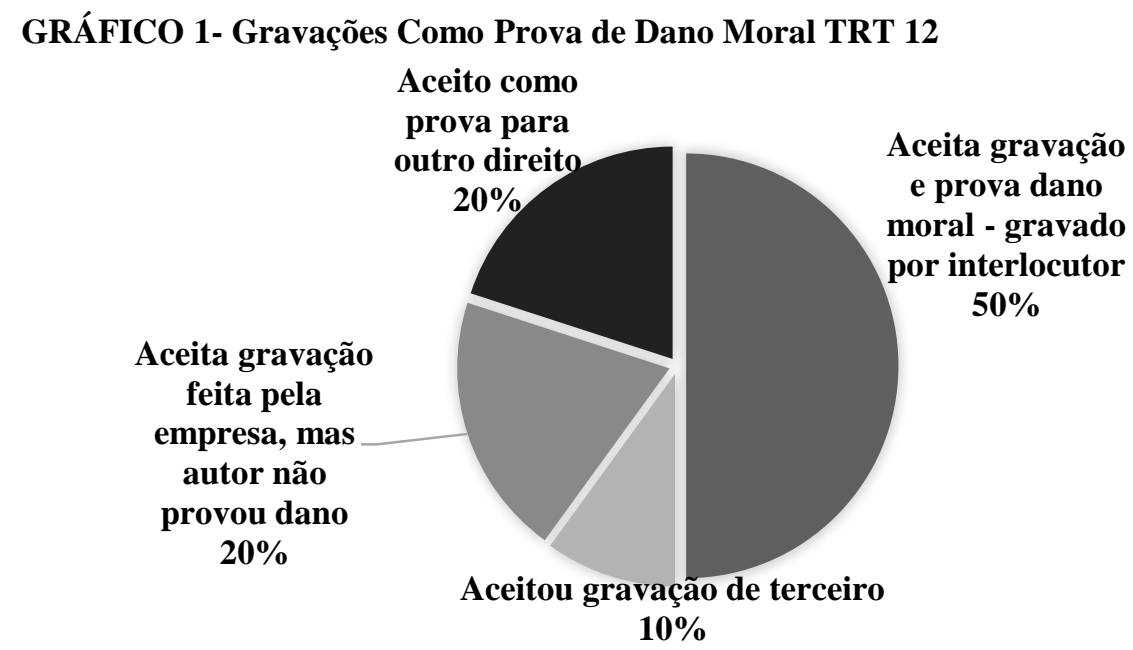

FONTE: os autores.

O que se observa dos resultados é que a maioria das decisões (50\% - 5 decisões) aceitaram as gravações como prova no dano moral, desde que gravado por um dos interlocutores. Sobre outras temáticas, como gravações realizadas pela empresa ou prova de outro dano encontra-se $40 \%$ (4 decisões).

Ressalta-se que uma decisão (10\%) aceitou que um terceiro gravasse uma conversa entre o empregador e ele, para comprovar que o empregador estava fornecendo informações depreciativas sobre o autor. (BRASIL, Tribunal Regional da 12a região. Acórdão n ${ }^{\circ}$ 00965-2011013-12-00-4) Tal decisão é paradigmática para o estudo da matéria, pois como será observado, a maioria das decisões não aceita que terceiros realizem a gravação.

\subsection{TRT 3 Minas Gerais}

No TRT 3 de Minas Gerais foram encontradas 7 decisões $^{9}$ e ressalta-se o principal problema de pesquisa, novamente, foram os poucos resultados. Os resultados foram sintetizados no gráfico 2 .

\footnotetext{
8 Todas as decisões são apresentadas no Anexo 1.
}

9 Todas as decisões são apresentadas no Anexo 1. 


\section{GRÁFICO 2 - Gravações como prova de dano moral TRT 3}

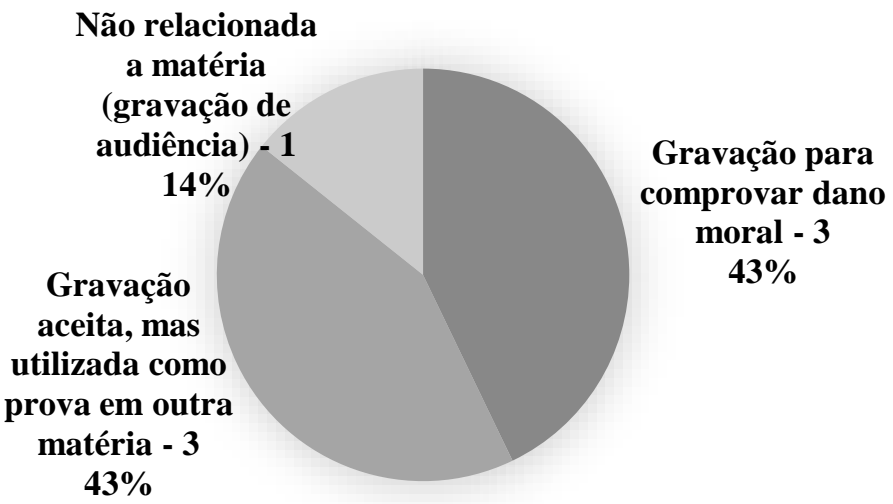

FONTE: os autores

O que se observa é que $43 \%$ (3 decisões) das decisões aceitaram as gravações como prova no dano moral, desde que gravado por um dos interlocutores, e não relacionado com a matéria ou voltado a prova de doutro direito, tem-se $57 \%$ (4 decisões)

Destaca-se a decisão em que o autor realizou pedido de danos morais por pagamento extra folha (comprovado pela gravação), o qual foi indeferido pelo entendimento do juízo de que dano patrimonial não gera dano moral. (BRASIL, Tribunal Regional da $3^{\mathrm{a}}$ região. Acórdão $\mathrm{n}^{\circ}$ 0011864-29.2016.5.03.0143)

\subsection{TRT 23 Mato Grosso}

No TRT 23 do Mato Grosso foram encontradas 4 decisões ${ }^{10}$ e ressalta-se o principal problema de pesquisa, novamente, foram os poucos resultados. Os resultados foram sintetizados no gráfico 3.

\footnotetext{
10 Todas as decisões são apresentadas no Anexo 1.
} 
A prova do dano moral no processo do trabalho: o entendimento dos tribunais sobre a possibilidade da utilização da gravação e as novas tecnologias de comunicação

\section{GRÁFICO 3 - Gravações como prova de dano moral TRT 23}

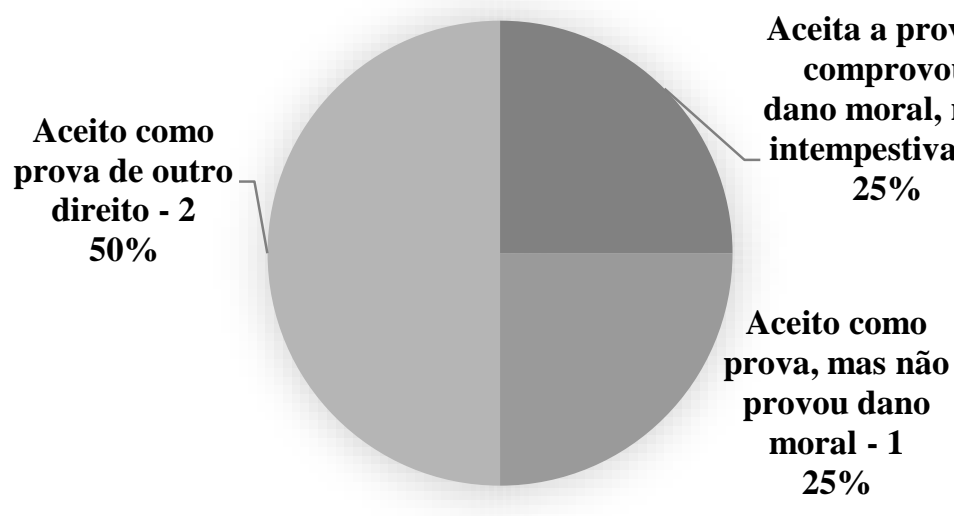

FONTE: os autores

Observa-se que todas as gravações foram aceitas como prova, sendo 50\% (2 decisões) para outros direitos e 50\% (2 decisões) para dano moral. Entretanto, nenhum foi efetiva, pois, 1 foi intempestiva e a outra apesar de aceita, não comprovou o dano.

\subsection{TRT 22 Piauí}

No TRT 22 do Piauí foi encontrada apenas 1 decisão ${ }^{11}$ e ressalta-se que aparentemente apenas um resultado deveria ser descartado, entretanto, este se demonstrou paradigmático e optou-se por manter no presente estudo.

Tal decisão foi completamente contra toda a tendência que começou a ser desenvolvida no presente estudo: aceitou-se a gravação como prova de dano moral, entretanto somente podese utilizar essa prova se não houver qualquer outra no processo. (BRASIL, Tribunal Regional da $22^{\mathrm{a}}$ Região. Recurso Ordinário n ${ }^{\circ}$ 0000490-54.2015.5.22.000).

\subsection{TRT 8 Pará e Amapá}

No TRT 8 do Pará e Amapá foram encontradas 30 decisões ${ }^{12}$, sendo o único tribunal que efetivamente apresentou vários resultados, apresentados no gráfico 4 .

\footnotetext{
11 Todas as decisões são apresentadas no Anexo 1.
}

12 Todas as decisões são apresentadas no Anexo 1. 


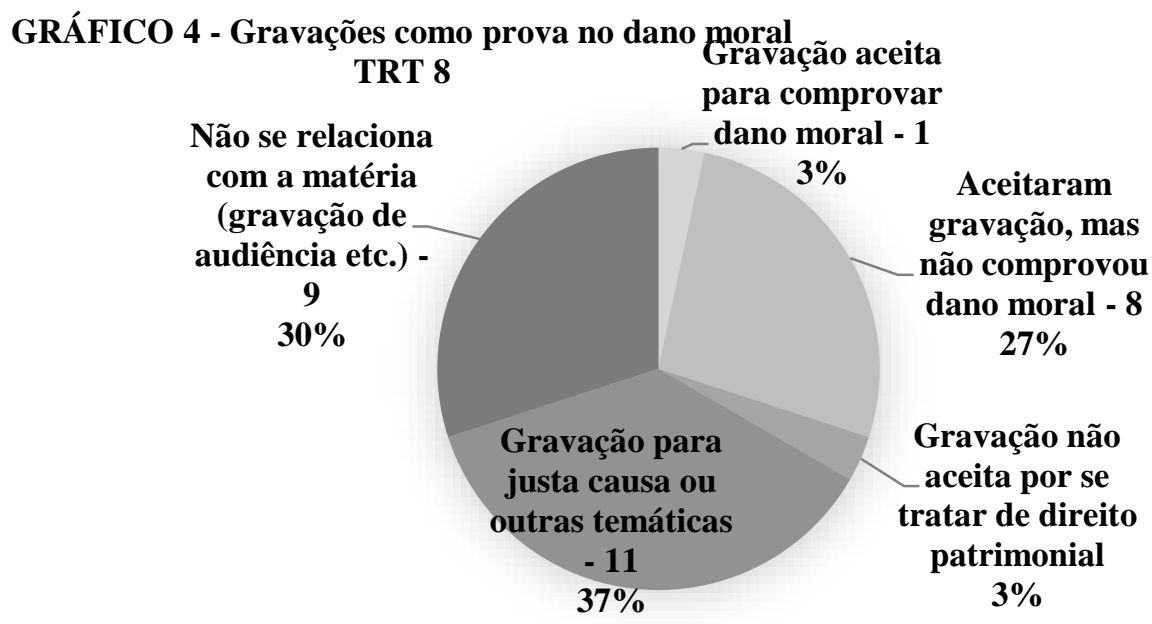

FONTE: os autores

Observa-se que somente $3 \%$ (1 decisão) efetivamente aceitou a gravação como prova de dano moral, destaca-se que $27 \%$ (8 decisões) aceitaram, mas não foi entendido que comprovou o dano moral. $40 \%$ (12 decisões) foram gravações para provar outro direito e $30 \%$ ( 9 decisões) se referiam a outros tipos de gravação.

Da análise realizada observa-se que este tribunal apresenta uma maior inflexibilidade quanto a consideração da gravação como efetiva prova e resultar em dano moral, mas para uma posição objetiva seria necessária a análise caso a caso.

Como exemplo cita-se a decisão em que o empregador desconfiava que os empregados estariam vendo óleo da empresa, e por isso realizou-se uma primeira abordagem e posteriormente foram instaladas câmeras de vigilância devido a tal desconfiança. Não foi considerado como causa de dano moral. (BRASIL, Tribunal Regional da $8^{\mathrm{a}}$ Região. $\mathrm{n}^{\circ} 0000960$ 72.2015.5.08.0004)

A única gravação aceita como prova de dano moral foi a em que o empregador estava cobrando a execução de várias atividades "utilizando termos vulgares". Ressalta-se que o valor da condenação foi mantido conforme a decisão de primeiro grau. (BRASIL, Tribunal Regional da $8^{\text {a }}$ Região. $n^{\circ}$ 0001785-26.2015.5.08.0130)

Dessa forma, das análises das cinco regiões é possível trazer alguns resultados: i. Gravação realizada por interlocutor é aceita para provar dano moral; ii. Gravação realizada por interlocutor para provar dano patrimonial, geralmente não é aceita; iii. Gravação por terceiro, geralmente não é aceita; iv. Santa Catarina (representante da região sul) tendem a ser mais flexível e condenar a dano moral; v. Estados do norte (Pará e Amapá) tendem a adotar uma posição restritiva a condenação por dano moral. Refutou-se a tese inicial de que não haveriam diferenças de regionalidades. 
A prova do dano moral no processo do trabalho: o entendimento dos tribunais sobre a possibilidade da utilização da gravação e as novas tecnologias de comunicação

\section{A POSSIBILIDADE DE GRAVAÇÃO: O ENTENDIMENTO DO Tribunal SUPERIOR do TrabalHo E do SUPREMO TribUNAL FEDERAL}

A segunda pesquisa de jurisprudência foi realizada no sítio eletrônico do Tribunal Superior do Trabalho com o termo "gravação", e com o objetivo de realizar uma pesquisa mais ampla, utilizou-se o marco temporal de 2000 a 2017. Ao todo foram encontradas 112 decisões. ${ }^{13}$ Os resultados estão apresentados no gráfico 5 .

\section{GRÁFICO 5- GRAVAÇÕES COMO PROVA DE DANO MORAL -}

\section{TST}

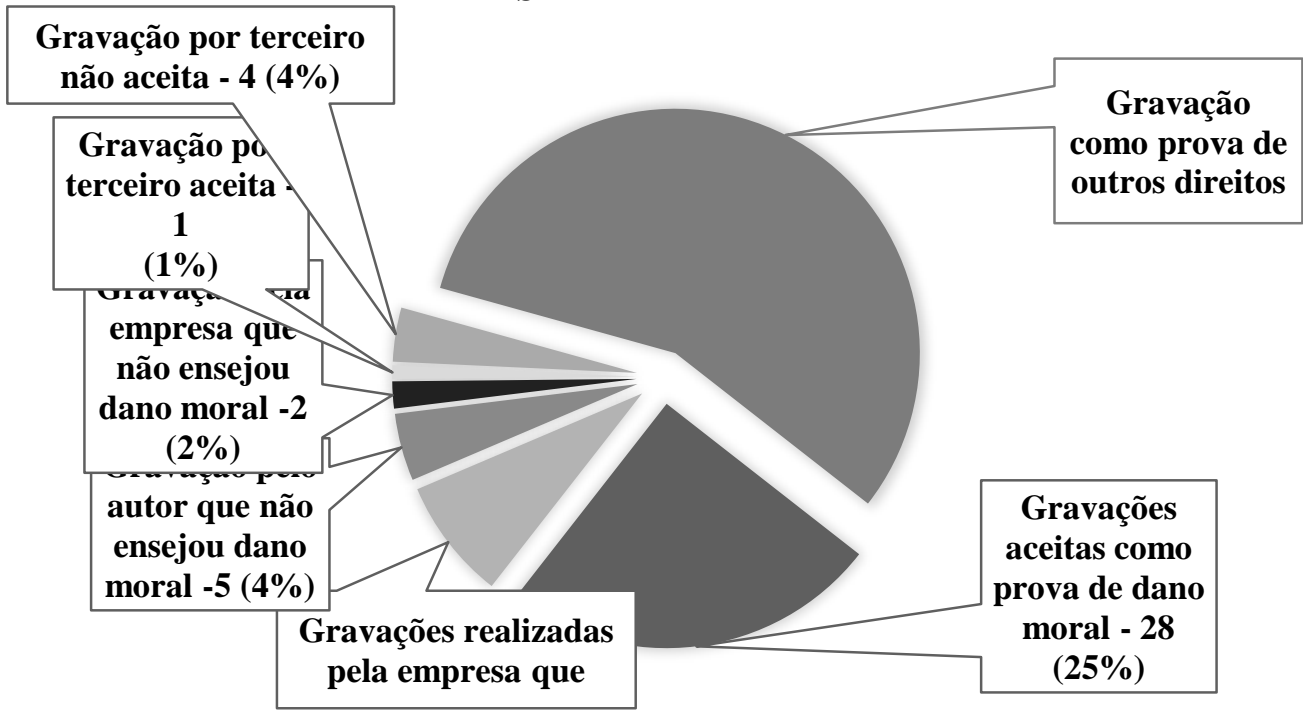

FONTE: os autores. ${ }^{14}$

Observa-se que 56\% (63 decisões) se tratam de gravações como prova de outros direitos ou de temática não correlata; $25 \%$ (28 decisões) foram favoráveis a utilização da gravação como prova de dano moral, $8 \%$ (9 decisões) se trata de gravações realizadas pela empresa que ensejaram dano moral ${ }^{15} ; 4 \%$ (5 decisões) aceitaram a gravação, mas não ensejou dano moral; destaca-se que $4 \%$ (4 decisões) não aceitaram gravação realizada por terceiro como prova de dano mora; $2 \%$ (2 decisões) trataram de gravação pela empresa que não ensejou dano moral; e apenas $1 \%$ (1 decisão) aceitou gravação realizada por terceiro como prova de dano moral.

Uma das decisões que se presta a demonstrar a generalidade dos casos em que há o aceite da gravação como prova de dano moral e a condenação, é a que traz o caso da "lista suja", ou como intitulado pelo tribunal, "lista negra". O reclamante gravou a conversa, sendo ele um dos interlocutores, com o intuito de comprovar a prática discriminatória das reclamadas, que disseminavam "informações desabonadoras de ex-empregados que acionam seus ex-patrões na

13 Todas as decisões são apresentadas no Anexo 1.

${ }^{14} \mathrm{O}$ sistema percentual adotado arredonda os valores para decimais inteiros, ou seja, sem casas decimais após a vírgula.

15 Gravação de revista íntima, de banheiros, ou ainda, a utilização pelo empregado de e-mail da empresa para assediar outras empregadas, como é o caso da decisão: BRASIL, Tribunal Superior do Trabalho. Agravo de Instrumento em Recurso de Revista n 1461-48.2010.5.10.0003. 
Justiça do Trabalho, a chamada 'lista negra"'. (BRASIL, Tribunal Superior do Trabalho. Recurso de Revista $n^{\circ}$ 60800-64.2005.5.17.0181) A gravação se mostrou um mecanismo eficaz para comprovar o dano moral nessas situações.

Em um segundo momento, observa-se que a gravação realizada por terceiro não interlocutor é geralmente recusada como meio probatório, como se observa do caso paradigma, que consolida diversas decisões e seus fundamentos. (BRASIL, Tribunal Superior do Trabalho. Recurso de Revista $\left.n^{\circ} 761175-81.2001 .5 .12 .5555\right)$ No caso, o autor acostou aos autos uma gravação do reclamado com terceiro, com o objetivo de provar um pedido de dano moral. $\mathrm{O}$ Tribunal Regional da 12a Região (Santa Catarina) negou provimento ao recurso ordinário, mantendo a sentença de primeiro grau que determinou a ilicitude da gravação de conversa realizada por terceiro não interlocutor. O Tribunal Superior do Trabalho manteve as decisões, por força do Art. 5ㅇ, XIII, da CRFB, que dispõe sobre a inviolabilidade do sigilo de correspondência e das comunicações telegráficas, telefones e etc. Ressalta ainda que a jurisprudência do STJ e do STF está consolidada em apenas aceitar gravação como meio de prova, quando um dos interlocutores a tiver realizado.

Destaca-se que a única decisão que deferiu a gravação realizada por terceiro como prova de dano moral (BRASIL, Tribunal Superior do Trabalho. Recurso de Revista $\mathrm{n}^{\circ} 16400$ 26.2009.5.13.0022) foi realizada pelo amigo do reclamante, e foi aceita como prova e ensejou a condenação, dessa forma, trata-se de apenas um caso, pelos critérios e metodologias utilizadas, que aceitou e condenou à responsabilização dessa maneira.

Dessa forma, constata-se a consolidação da jurisprudência sobre a possibilidade de gravação por um dos interlocutores como prova de dano moral e destacou-se as situações excepcionais e que demonstram a ocorrência de gravação por terceiro, sendo o percentual de diferença entre aceitação e negação muito ínfimo.

Com relação ao Supremo Tribunal Federal realizou-se uma pesquisa qualitativa com o objetivo de traçar alguns casos paradigmas sobre a temática, já que como se observa das pesquisas realizadas anteriormente, sempre se cita a jurisprudência consolidada do STF. Destacase então, dois precedentes que atuam como norte para as decisões infra, os dois casos escolhidos tratam-se de matéria penal, e apresenta-se o precedente firmado, o qual destaca-se:

\footnotetext{
O presente caso versa sobre a gravação de conversa telefônica por um interlocutor, sem o consentimento de outro, isto é, a denominada "gravação telefônica" ou "gravação clandestina". Entendimento do STF no sentido de licitude da prova, desde que não haja causa legal específica de sigilo nem reserva de conversação. Repercussão geral da matéria (RE 583.397/RJ) (BRASIL, Supremo Tribunal Federal. Habeas Corpus $n^{\circ}$ 91613; BRASIL, Supremo Tribunal Federal. Agravo de Instrumento $\mathrm{n}^{\circ} 560223$. )
}

Dessa forma, observa-se da pesquisa realizada que já há precedente firmado sobre a questão, ou seja, a possibilidade da utilização de gravação como prova de dano moral, mas que este fato não exauriu a questão, ainda é possível discutir a possibilidade de gravação de terceiro, principalmente diante da pesquisa regional que se realizou anteriormente. 
A prova do dano moral no processo do trabalho: o entendimento dos tribunais sobre a possibilidade da utilização da gravação e as novas tecnologias de comunicação

\section{A POSSIBILIDADE DA UTILIZAÇÃO DA GRAVAÇÃO E NOVAS TECNOLOGIAS DE COMUNICAÇÃO NO TRIBUNAL REGIONAL DO TrabalHo da 9a Região - PARANÁ}

Realizou-se por fim, uma pesquisa no Tribunal Regional do Trabalho da 9a Região (Paraná), a qual utilizou-se duas metodologias diferentes: pesquisa pelo termo "gravação" nas ementas de 2004 a 2016 e a segunda por amostragem, voltada a utilização de novas tecnologias como meio de prova.

Não utilizou-se o referido tribunal na pesquisa por região, pois só era possível, pelo site do referido órgão, o acesso às ementas das decisões, então, não seria possível a verificação das decisões por completo, e também, pois não se encontrou decisões com o referido filtro no ano de 2017 e 2018. Por esse motivo, optou-se por realizar uma pesquisa em separado deste tribunal.

Destaca-se primeiro a pesquisa quantitativa, realizada com a linha temporal de 2004 a 2016, com o termo "gravação" na ementa. Os dois principais problemas encontrados na referida pesquisa foram a disponibilização somente das ementas, o que resultou na dificuldade de saber se a "gravação" se referia ao dano moral; e o fato de o site disponibilizar decisões somente a partir de 2004. Foram encontradas 33 decisões $^{16}$ e os resultados foram sintetizados no gráfico 6:

\section{GRÁFICO 6 - GRAVAÇÕES COMO PROVA DE DANO MORAL - TRT9}

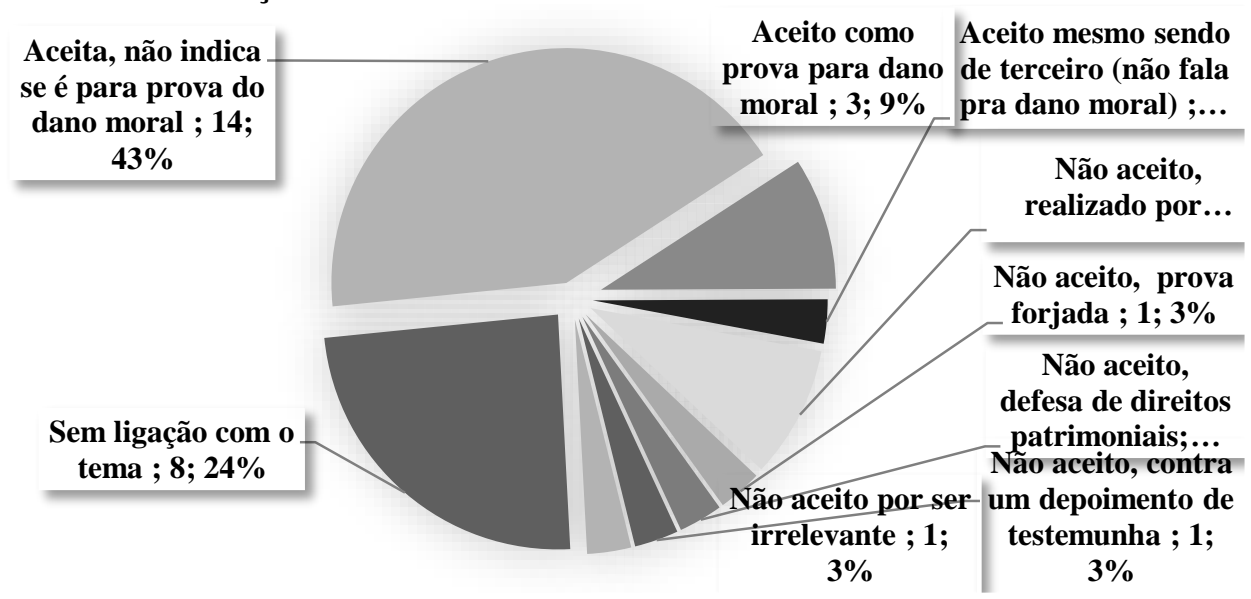

FONTE: os autores.

Observa-se em um primeiro momento o problema da pesquisa: 43\% (14 decisões) das decisões aceitaram as gravações, mas não indica na ementa se era para comprovar dano moral; $24 \%$ (8 decisões) não possuíam relação com o tema; $9 \%$ (3 decisões) aceitavam a gravação como prova de dano moral (estava explícito na ementa); $9 \%$ (3 decisões) não aceitaram por se tratar de gravação realizada por terceiro (seguindo então a tendência nacional); $3 \%$ (1 decisão) aceita gravação por terceiro, mas não informado sobre o que dizia respeito; $12 \%$ (4 decisões) decisões não aceitaram por: ser prova forjada, por se tratar de defesa de direitos patrimoniais, por ir contra o depoimento de uma testemunha e por ser irrelevante ao processo.

\footnotetext{
16 Todas as decisões são apresentadas no Anexo 1.
} 
Destaca-se a decisão em que não se aceitou a gravação realizada por um dos interlocutores, por ter como objetivo comprovar fato de natureza pecuniária, por esse motivo a prova é considerada ilícita com fundamento no art. 5 LVI da CRFB/1988, afirmando-se que se poderia flexibilizar a norma constitucional somente em caso de direito personalíssimo. (BRASIL, Tribunal Regional da $9^{a}$ Região. Processo n 12202-2006-012-09-00-9-ACO-19014-2009)

Merece evidência a decisão em que se negou a gravação realizada por terceiro estranho a lide, devido as circunstâncias do caso concreto, pois em realidade a esposa do reclamante utilizou-se de falsa identidade com o intuito de provocar a situação ora gravada, para dar suporte a ação trabalhista em voga. Por esse motivo a prova foi considerada como ilícita. (BRASIL, Tribunal Regional da 9 ${ }^{a}$ Região. Processo nº 01680-2006-670-09-00-3-ACO-15802-2011)

Dessa forma observou-se uma séria dificuldade quanto a indeterminação do fato a que a prova buscava demonstrar, mas consolidou-se a ideia de gravação por um dos interlocutores como legítima e ainda, da impossibilidade de gravação por terceiro.

Ademais, cabe ressaltar a segunda pesquisa realizada no presente tribunal, a este ponto por amostragem, na qual selecionou-se casos paradigmáticos na questão de produção de provas por meios não tradicionais, ou seja, a utilização de meios eletrônicos, com o objetivo de traçar o entendimento e comportamento do referido tribunal. Para tanto, foram selecionados cinco julgados. ${ }^{17}$

O primeiro caso foi julgado em 2005 e na presente situação não foi considerado o "email" como meio fidedigno de prova, sob o argumento de que não há assinaturas, possibilidade de alteração, e a facilidade de cadastramento de dados pessoais sem comprovação, e que a utilização deste representaria apenas um indício e não uma prova. Ressalta-se a historicidade da decisão, em que no momento não havia a facilidade da assinatura eletrônica e os e-mails começavam a ser utilizados como meio de prova e também a atualidade da decisão, pois ressaltava a facilidade de adulteração da referida prova. (BRASIL, Tribunal Regional da $9^{a}$ Região. Processo nº 00990-2004-660-09-00-1-ACO-28662-2005)

Atualmente, observa-se que vêm se perdendo esse cuidado com as provas digitais, que são aceitas irrestritamente e sem a exigência de qualquer mecanismo que comprove a sua autenticidade. (GICO JÚNIOR, 2001)

Em contrapartida destaca-se uma das poucas decisões em que se exigiu algum tipo de comprovação da veracidade da prova, foi em 2016, na qual exigiu-se que mensagens do aplicativo "whatsapp" fossem transcritas por meio de ata notarial realizada em cartório, somente assim poderia ser utilizada como prova: "A mera juntada unilateral por uma das partes não serve como prova, haja vista ausência de autenticação da veracidade do seu conteúdo, em face da possível manipulação das informações”. (BRASIL, Tribunal Regional da 9a Região. Processo $\mathrm{n}^{\circ}$ 09172-2014-872-09-00-2-ACO-29267-2016)

A próxima decisão, a título de exemplo, tratou da possibilidade de o "facebook" servir como prova de dano moral em um processo, no caso em tela, foi aceito como prova, mas por não se tratar de uma conduta relevante, não ensejou na condenação em dano moral. (BRASIL, Tribunal Regional da $9^{a}$ Região. Processo n ${ }^{\circ}$ 04068-2015-651-09-00-5-ACO-07382-2017)

No caso em tela a preposta da empresa convidou colegas de trabalho, fora do horário de trabalho, para participarem de grupo do "facebook", com conteúdo não relacionado ao trabalho, entendeu-se que decorria de uma relação pessoal e não do trabalho, e somente o convite para participar de um grupo não ensejaria a condenação.

17 Todas as decisões são apresentadas no Anexo 1. 
A prova do dano moral no processo do trabalho: o entendimento dos tribunais sobre a possibilidade da utilização da gravação e as novas tecnologias de comunicação

O próximo julgado diz respeito à utilização de vídeo como prova de dano moral, no presente processo o reclamante foi amarrado por colegas de trabalho da empresa no vestiário. A turma ressaltou que o fato de que a "própria "vítima" induzia a tanto, pois ria de si própria" não ensejou a diminuição da responsabilidade da empresa. (BRASIL, Tribunal Regional da 9a $\operatorname{Re}-$ gião. Processo no 05745-2011-024-09-00-7-ACO-34400-2012)

O último caso trata-se da cumulação da prova por vídeo, mensagem e testemunhal, que juntas corroboraram para a condenação em dano moral. No caso em tela, a autora trabalhava com outro empregado que a assediava, mandando mensagens "com textos bastantes fortes sob o ponto de vista sexual" e ainda, a testemunha confirmou as gravações da empresa: "imagens do sistema de monitoriamento, onde aparece o Sr. Ayrton tentando beijar a autora a força". (BRASIL, Tribunal Regional da 9 ${ }^{a}$ Região. Processo nº40096-2009-010-09-00-3-ACO-079462014)

Dessa forma, dessa análise qualitativa observa-se que: i. Anteriormente ainda tentava-se exigir que provas produzidas por meio eletrônico fossem confirmadas por meios oficiais; ii. A tendência atual é que tal exigência se consolida em raras exceções; iii. Há a possibilidade da utilização também do "facebook" como meio de prova, mas deve-se atentar a realização de dano efetivo, ou seja, não é qualquer ato virtual que ensejará em dano; iv. Consolidada a utilização de vídeo como prova de dano moral; v. A melhor forma de garantir a composição probatória é atribuir diversos meios de prova, como gravações, testemunha, documentos e etc.

A próxima análise será direcionada aos problemas que as provas realizadas por meios tecnológicos podem trazer para composição probatória de um processo.

\section{OBSTÁCULOS À VALIDAÇÃO E CONFIABILIDADE DAS PROVAS REALIZADAS POR MEIOS TECNOLÓGICOS E POSSÍVEIS FORMAS DE SUPERAÇÃO}

Cabe a este momento destacar pontos de fragilidade da prova nas pesquisas aqui demonstradas e também nas observações por parte da doutrina da referida temática. Observa-se que em nenhum julgado da pesquisa nas cinco regiões e do tribunal superior do trabalho foram observadas quaisquer requisições ou métodos para atestar a veracidade das gravações. Na pesquisa realizada no Tribunal Regional do Trabalho da $9^{\text {a }}$ região somente foi encontrado aqueles dois casos paradigmas, um que recusou a utilização de e-mail por não ser uma prova fidedigna, tal recusa pode ter sido justificada pela data do acórdão (2005), e o outro caso de 2016 exigiu a utilização de ata notarial para atestar a veracidade de prova produzida pelo "whatsapp".

Observou-se que a ampla maioria das decisões aceita a gravação por um dos interlocutores como prova de dano moral e alguns tribunais possuem esparsas decisões sobre a possibilidade de terceiro efetuar a gravação, mesmo com alguns precedentes nos tribunais superiores contrários. Cresce ainda, como visto no TRT9 ${ }^{a}$ região, as possibilidades de utilização de novas tecnologias como meio de prova no processo do trabalho e em especial, como prova de dano moral.

Entretanto, o crescimento das possibilidades tecnológicas probatórias não vem acompanhado de formas de verificar a autenticidade delas. A fragilidade da prova está exatamente em não se realizar o procedimento de verificação dessas provas. 
A utilização de novas tecnologias como forma probatória está adstrita a realidade da vivência das novas formas de comunicação, um resultado da própria globalização e ampliação da utilização dos meios tecnológicos. Segundo Diana Carolina Valencia Tello a era da globalização ${ }^{18}$ possui cinco aspectos fundamentais: i. fortalecimento do mercado e enfraquecimento dos Estados; ii. Como os avanços técnicos e científicos contribuíram para o fortalecimento do capitalismo; iii. Aumento da comunicação e interdependência entre as pessoas, sociedade e o mundo; iv. Criação de redes autônomas e independentes que aumentam as comunicações entre indivíduos pertencentes a essas redes; v. Aumento do risco de produção de danos irreparáveis ou muito onerosos. (TELLO, 2015, p. 20-21)

Denota-se que a presente pesquisa trata-se diretamente dos meios de comunicação, a criação de redes autônomas entre os indivíduos, e a possibilidade de ampliar os riscos de danos, principalmente pela falsa ideia de anonimato e ausência de responsabilização nas redes sociais. (SILVEIRA, 2009)

Segundo a pesquisa realizada pela Digital Future in Focus em 2015 sobre a realidade brasileira, os usuários da internet móvel cresceram 7\% no Brasil do segundo semestre de 2014 ao primeiro semestre de 2015, alcançando o patamar de correspondendo a quase 39 milhões usuários. O facebook alcançou $78 \%$ do total de usuários únicos no Brasil, possuindo mais de 58 milhões de visitantes únicos mensais. Ainda, o Brasil é líder global em relação ao tempo gasto em cada visita a redes sociais (em média 21,2 minutos por visita), o tempo gasto é $60 \%$ maior do que a média mundial, alcançam uma média mensal de 9.7 horas por visitante, 650 horas nas redes sociais por mês, 290 horas a mais do que em outros portais. (DIGITAL FUTURE IN FOCUS BRAZIL, 2015)

O que ocorre é a vivência no ciberespaço, que não busca somente tornar a vida mais fácil e sim, "diferente, ou, quem sabe, melhor, criando meios de interação que não eram possíveis antes”. (LESSIG, 2006, p. 83) Existe uma diferenciação entre as interações no mundo real e nos espaços virtuais, nesses últimos o código é a lei ${ }^{19}$

Desde o surgimento do ciberespaço até a atualidade tem-se a ideia de que o "espaço cibernético" não pode ser regulado, e há várias afirmações de que sua eventual "natureza" não permitiria regulações e uma possível governabilidade,${ }^{20}$ entretanto há uma dificuldade maior, mas é possível a sua regulamentação. ${ }^{21}$

Observa-se que a tendência do anonimato vem se transformando, a tendência atual é um padrão de identificação dos usuários e o etiquetamento dos conteúdos, uma vez que as tecnologias ligadas a comportamento online, como identidade de usuários, algoritmos de personalização, tem alcançado uma evolução constante. (LESSIG, 2006, p. 38)

Dessa forma, responsabilizações por atos realizados na internet são recorrentes e crescem a cada dia, e inclusive, como demonstrado, a utilização desses meios como mecanismos de

\footnotetext{
18 Alguns autores intitulam esse período como pós-modernidade. BAUMAN, 2001.

${ }^{19}$ Código entendido aqui como código fonte, que descreve a linguagem de programação. LESSIG, 2006, p.89.

${ }^{20}$ Como foi referenciado na "Declaração de Independência do Ciberespaço", publicada por John Perry Barlow, fundador da Eletronic Frontier Foundation: "Vocês [os governos] não possuem nenhum direito moral de nos governar, nem possuem quaisquer métodos de coerção que teríamos razão de temer. [...] Essa governança vai surgir de acordo com as condições do nosso mundo, e não do seu. Nosso mundo é diferente". BARLOW, 1996, tradução nossa.

${ }^{21}$ Dez anos depois, Barlow esclareceu: "Eu quis explicar o estado natural da liberdade da internet, ou, ao menos, a improbabilidade de que as interações humanas que ocorreriam nesse novo espaço social fossem um dia se tornar inteiramente obedientes à soberania dos governos existentes. [...] Minha crença nos benefícios de dar voz a toda humanidade não levou em conta o que aconteceria se você desse a um bilhão de pessoas o seu próprio palanque e sua esquina de rua. Todos estão falando e ninguém está ouvindo. É como poesia. Muitos escrevem e poucos leem." BARLOW, 1996, tradução nossa.
} 
A prova do dano moral no processo do trabalho: o entendimento dos tribunais sobre a possibilidade da utilização da gravação e as novas tecnologias de comunicação

prova. O processo e o judiciário está sendo tomado pelas novas tecnologias de comunicação em todas as suas particularidades e possibilidades.

Ressalta-se então, nesse momento, a necessidade de incorporar mecanismos de fiscalização e verificação da autenticidade probatória. A realidade demonstra que da forma como as provas são acostadas ao processo: áudios são anexados por CD'S (mais atualmente utiliza-se pendrive em alguns juízos); conversas ou situações vislumbradas por e-mail, "whatsapp", "facebook" ou outros mecanismos são apenas capturadas e anexadas as petições; sem qualquer verificação de veracidade.

Ressalta-se algumas técnicas que podem ser utilizadas para maquiar ou fraldar provas: i. a nível básico ${ }^{22}$ as conversas e áudios podem ser alteradas por simples edição de foto ou de áudio, inclusive por aplicativos de celulares (COSTA, 2015); iii. Há diversos tutoriais disponíveis ao primeiro clique no google que ensinam a "forjar um e-mail" (WIKIHOW, 2018), ou criar conversas falsas no facebook (RIBEIRO,2013) ii. O aplicativo "whatsapp" já permite duas modalidades para apagar alguma fala em uma conversa: uma opção é direcionada somente ao usuário e a outra deixa o rastro, para todos da conversa, de "mensagem apagada". (CABRAL, 2018) Considerando que as provas são acostadas aos processos pelo próprio usuário e que a empresa até o presente momento não entrega os dados de histórico de conversa ${ }^{23}$, há uma imensa brecha na autenticidade probatória; iii. A utilização de aplicativos que simulam conversas completamente falsas como "Whatsfake". ${ }^{24}$

Ainda, é possível a realização da falsificação por profissionais: iv. Dois engenheiros da computação, Jaime Sánchez e Pablo San Emeterio, especializados em segurança cibernética, conseguiram quebrar o código do WhatsApp modificando o remente de uma mensagem, simulando que uma pessoa encaminhasse mensagens para outra. ${ }^{25} \mathrm{v}$. Um grupo de pesquisadores suíços da École Polytechnique Fédérale de Lausanne encontraram uma série de falhas na criptografia do Whatsapp, e conseguiram incluir pessoas em grupos sem que o administrador autorizasse e assim, coletando todas as informações. (GARIMELLA; TYSON, 2018).

Dessa forma, demonstra-se há inúmeras formas de falsificação dos meios digitais que usualmente são utilizados como prova em processos judiciais. Ainda, demonstrou-se que em ínfimas situações utilizou-se de recursos para comprovar a autenticidade, como a biometria que identifica padrões de voz, exame de retina, impressões digitais e etc.(LEAL, 2007, p.159); a assinatura digital ${ }^{26}$, que segundo Sérgio Iglesias Nunes de Souza é a única forma de se admitir como meio de prova um e-mail (SOUZA, 2009, p.83); a própria "computação forense"27, seriam os peritos técnicos para averiguar a veracidade de um documento ou prova digital e o recurso utilizado foi a ata notarial.

A ata notarial está primeiramente disposta no art. 384 do CPC que permite que seja atestado em cartório e lavrada uma certidão sobre determinado áudio ou imagem, entretanto, é uma

${ }^{22}$ Textos, imagens ou sons, são facilmente modificados pelos próprios programas de computador que os produziram, ou ainda, por programas que permitem a sua edição "byte por byte". LEAL, 2007, p.155.

${ }^{23}$ A empresa afirma que absolutamente ninguém (nem ela mesma) consegue acessar o conteúdo dos usuários e para disponibilizar tal conteúdo ela teria que alterar todo o seu sistema de criptografia. GAZETA DO POVO, 2017.

${ }^{24}$ O próprio site do aplicativo utiliza o slogan "Crie conversas falsas" e "Com o WhatsFake você rapidamente simula conversas bem realistas e envia a todos os seus amigos". WHATSFAKE, s.d.

${ }^{25}$ Ressalta-se que os dois profissionais conseguiram encontrar diversas formas de infiltrar na segurança do aplicativo: espionaram conversas, decifraram senhas e códigos pessoais, fabricaram mensagens. Todas essas foram solicionadas pela empresa, exceto a mais recente apresentada: a modificação de remetente. GOSÁLVEZ, 2014.

26 A medida provisória 2.200-2/01 que instituiu uma Infraestrutura de Chaves Públicas para o Brasil, buscou ampliar a utilização da assinatura digital. (BRASIL, Medida Provisória $n^{\circ}$ 2.200-2/ 2001.)

27 “A computação forense consiste no uso de métodos científicos na preservação, coleta, validação, identificação, análise, interpretação, documentação e apresentação de evidências digitais”. (PINHEIRO, 2009, p.171) 
faculdade e não uma obrigatoriedade, sendo possível pelo art. 225 do CC que tais provas sejam acostadas aos autos sem necessariamente passar pela lavratura em cartório: "fazem prova plena destes, se a parte, contra quem forem exibidos, não lhes impugnar a exatidão".

Dessa forma, observa-se que a fragilidade das provas digitais é inerente a elas, e os tribunais não vêm acompanhando a evolução dessas tecnologias, não sendo exigido a comprovação da veracidade. Mesmo no caso de impugnação da referida prova, não são utilizados os meios existentes e possível para a verificação. As possíveis formas de superação da fragilidade da referida prova estão em um primeiro momento a exigência de que a referida prova esteja certificada por um cartório; em um segundo momento, esses cartórios devem estar habilitados para detectar efetivamente a veracidade delas; e por fim, a ampliação de um sistema de perícia computacional que possibilitaria efetivamente garantir a veracidade das referidas provas. $\mathrm{O}$ direito precisa se adequar às possibilidades e riscos da tecnologia.

\section{CONCLUSÃo}

Apresenta-se nesse patamar as conclusões do estudo de forma estruturada:

I. É possível a flexibilização da necessidade probatória dos critérios rígidos da responsabilidade civil, quais sejam o fato ou próprio dano, o nexo causal e a culpa empresarial, a depender do caso concreto a que se depara.

II. A Lei no 13.467/2017, trouxe um avanço para a distinção teórica entre "dano moral" e “dano extrapatrimonial", na qual não se separa mais em várias categorias como dano moral, estético, existencial e patrimonial, agora há apenas duas: o dano patrimonial e o dano extrapatrimonial (e este congloba todos as relações não patrimoniais, ou seja, o moral, estético, existencial e etc).

III. A Lei $\mathrm{n}^{\circ} 13.467 / 2017$, não especificou a possibilidade do dano coletivo que possui caráter metaindividual, por esse motivo causa dúvidas sobre o possível dano em ricochete, e assim, a comprovação probatória no processo desse dano, possivelmente não será aceita.

IV. A reforma trabalhista, Lei $\mathrm{n}^{\circ} 13.467 / 2017$, consolidou o entendimento sobre o ônus da prova: o ônus do empregador provar fato impeditivo, modificativo ou extintivo e ônus do empregado a prova dos fatos constitutivos de seu direito. Ressalta-se que a reforma inovou ao prever que em casos específicos (por previsão legal ou pela dificuldade concreta) em que se vislumbre a impossibilidade ou à excessiva dificuldade de cumprir com o ônus da prova, poderá o juízo atribuir o ônus da prova de modo diverso.

V. Efetivamente a alteração mais controversa da reforma trabalhista trata-se do disposto no art. 223-G que estipula o que o juiz deverá considerar para avaliar o dano moral, como por exemplo a intensidade do sofrimento ou da humilhação, a possibilidade de superação física ou psicológica, os reflexos pessoais e sociais da ação ou omissão, a extensão e duração dos efeitos da ofensa e etc. Tal temática não vem sendo debatida e principalmente a quem caberá o ônus de provar todas essa situações, ou ainda, se isto restará apenas à convicção do juiz e sua análise dos fatos ocorridos.

VI. Observou-se o contraste formado: amplia-se a normativa relativa ao dano extrapatrimonial e por outro lado, pouco se discute quanto a fragilidade e novas formulações de prova. 
A prova do dano moral no processo do trabalho: o entendimento dos tribunais sobre a possibilidade da utilização da gravação e as novas tecnologias de comunicação

VII. A primeira pesquisa jurisprudencial realizada foi feita com o objetivo de traçar como os tribunais entendem a possibilidade da gravação como meio de prova no dano moral, através do mapeamento de um representante em cada uma das cinco regiões do Brasil: SUL no TRT 12 Santa Catarina; Sudeste no TRT 3 Minas Gerais; Centro- Oeste no TRT 23 Mato Grosso; Nordeste TRT 22 Piauí; e Norte TRT8 Pará e Amapá. Trouxe então, os resultados: i. Gravação realizada por interlocutor é aceita para provar dano moral; ii. Gravação realizada por interlocutor para provar dano patrimonial, geralmente não é aceita; iii. Gravação por terceiro, geralmente não é aceita; iv. Santa Catarina (representante da região sul) tendem a ser mais flexível e condenar a dano moral; v. Estados do norte (Pará e Amapá) tendem a adotar uma posição restritiva à condenação por dano moral.

VIII. A segunda pesquisa de jurisprudência foi realizada no sítio eletrônico do Tribunal Superior do Trabalho e constatou-se a consolidação da jurisprudência sobre a possibilidade de gravação por um dos interlocutores como prova de dano moral e destacou-se as situações excepcionais e que demonstram a ocorrência de gravação por terceiro, sendo o percentual de diferença entre aceitação e negação muito ínfimo.

IX. A terceira pesquisa realizada no Supremo Tribunal Federal buscou demonstrar o precedente já firmado sobre a questão, ou seja, a possibilidade da utilização de gravação como prova de dano moral. Destaca-se que este fato não exauriu a questão, ainda é possível discutir a possibilidade de gravação de terceiro, principalmente diante da pesquisa regional que se realizou anteriormente

X. As últimas duas pesquisas foram no Tribunal Regional do Trabalho da $9^{a}$ Região (Paraná), nas quais utilizou-se duas metodologias diferentes, uma quantitativa voltada a possibilidade de gravação e outra qualitativa voltada a utilização de novas tecnologias como meio de prova. Observou-se uma séria dificuldade quanto a indeterminação do fato a que a prova buscava demonstrar, mas consolidou-se a ideia da possibilidade da gravação por um dos interlocutores como legítima e ainda, da impossibilidade de gravação por terceiro. Da análise qualitativa observou-se que anteriormente ainda tentava-se exigir que provas produzidas por meio eletrônico fossem confirmadas por meios oficiais; não há a consolidação da exigência de veracidade, ocorrendo somente em raras exceções; há a possibilidade da utilização também do "facebook" como meio de prova, mas deve-se atentar a realização de dano efetivo, ou seja, não é qualquer ato virtual que ensejará em dano; consolidada a utilização de vídeo como prova de dano moral; por fim, a melhor forma de garantir a composição probatória é atribuir diversos meios de prova, como gravações, testemunha, documentos e etc.

XI. Observa-se que em nenhum julgado da pesquisa nas cinco regiões e do Tribunal Superior do Trabalho foram observadas quaisquer requisições ou métodos para atestar a veracidade das gravações, fato que só foi observado na pesquisa realizada no Tribunal Regional do Trabalho da $9^{\text {a }}$ região.

XII. Ressaltou-se a necessidade de incorporar mecanismos de fiscalização e de verificação da autenticidade probatória. A realidade demonstra que da forma como as provas são acostadas ao processo: áudios são anexados por CD'S, ou pendrive; conversas ou situações vislumbradas por e-mail, "whatsapp", "facebook" ou outros mecanismos são apenas capturadas e anexadas as petições; sem qualquer verificação de veracidade.

XIII. Demonstrou-se algumas técnicas que podem ser utilizadas para maquiar ou fraldar provas: i. conversas e áudios podem ser alteradas por simples edição de foto ou de áudio, inclusive por aplicativos de celulares; iii. tutoriais que ensinam a "forjar um e- 
mail”, ou criar conversas falsas no facebook ii. Os próproas possibilidades do aplicativo "whatsapp" de apagar alguma fala em uma conversa iii. A utilização de aplicativos que simulam conversas completamente falsas como "Whatsfake"; iv. Ainda, é possível a realização da falsificação por profissionais.

XIV.As possíveis formas de superação da fragilidade da referida prova estão em fortalecer os mecanismos de comprovação da veracidade e fiscalização no processo. Assim, institucionalizar a exigência de que a referida prova esteja certificada por um cartório, que estes devem estar realmente habilitados para detectar efetivamente a veracidade delas; e por fim, a ampliação de um sistema de perícia computacional que possibilitaria efetivamente garantir a veracidade das referidas provas.

Demonstrou-se então, que as mais diversas formas de tecnologia de comunicação já fazem parte das vivências humanas e estão sendo utilizadas como forma de comprovar danos extrapatrimoniais em processos judiciais. A sua utilização deve ser observada por parâmetros que permitam autenticar a sua veracidade e assim, o próprio processo deve se adaptar a tais tecnologias possibilitando mecanismos oficiais e extraoficiais de autenticação. Se trata da maneira mais segura de assegurar a fidedignidade do processo judicial.

\section{REFERÊNCIAS}

ASSIS, Araken de. Indenização do Dano Moral. Síntese Jornal, Porto Alegre,v.01, n.06, maio-junho/1997.

BARLOW, John P., A Declaration of the Independence of Cyberspace, 1996, disponível em<https://www.eff.org/cyberspace-independence>. Acesso em 20 de março de 2018.

BAUMAN, Zigmunt. Modernidade Líquida. Tradução: Plínio. Dentzien. Rio de Janeiro: Jorge Zahar, 2001.

BITTAR, Carlos Alberto: Reparação Civil por Danos Morais. Editora Revista dos Tribunais, São Paulo, 1. ed., 1993.

BRASIL, Conselho Nacional de Justiça. Justiça em Números 2017: ano-base 2016. Brasília: CNJ, 2017.

BRASIL, Medida Provisória no 2.200-2/ 2001. Institui a Infra-Estrutura de Chaves Públicas Brasileira - ICP-Brasil.

BRASIL, Supremo Tribunal Federal. Habeas Corpus no 91613. Relator: Gilmar Mendes Julgamento: 15 de maio de 2012. BRASIL, Supremo Tribunal Federal. Agravo de Instrumento $\mathbf{n}^{\mathbf{0}}$ 560223. Relator: Joaquim Barbosa Julgamento: 12 de abril de 2011.

BRASIL, Tribunal Regional da $12^{\mathrm{a}}$ região. Acórdão no 00965-2011-013-12-00-4. $5^{\mathrm{a}}$ Câmara. Relator: Maria De Lourdes Leiria

BRASIL, Tribunal Regional da $22^{\mathrm{a}}$ Região. Recurso Ordinário $\mathbf{n}^{\mathbf{0}} \mathbf{0 0 0 0 4 9 0 -}$ 54.2015.5.22.0003. Relator: Wellington Jim Boavista. Julgamento: 17 de abril de 2017.

BRASIL, Tribunal Regional da $3^{\text {a }}$ região. Acórdão $\mathbf{n}^{\mathbf{0}}$ 0011864-29.2016.5.03.0143. Relatora: Ana Maria Amorim Rebouças. Julgamento: 21 de fevereiro de 2018.

BRASIL, Tribunal Regional da $8^{a}$ Região. n⿳0 0000960-72.2015.5.08.0004. Relator: Georgenor de Sousa Franco Filho. Julgamento 7 de março de 2017. 
A prova do dano moral no processo do trabalho: o entendimento dos tribunais sobre a possibilidade da utilização da gravação e as novas tecnologias de comunicação

BRASIL, Tribunal Regional da $8^{a}$ Região. $\mathbf{n}^{\mathbf{0}}$ 0001785-26.2015.5.08.0130. Relatora: Maria Zuíla Lima Dutra. Julgamento 6 de fevereiro de 2018.

BRASIL, Tribunal Regional da $9^{a}$ Região. Processo n 00990-2004-660-09-00-1-ACO-286622005. Relatora: Marlene T. Fuverki Suguimatsu. Julgamento: 8 de novembro de 2005

BRASIL, Tribunal Regional da $9^{a}$ Região. Processo no 01680-2006-670-09-00-3-ACO-158022011. Relator: Sério Murilo Rodrigues Lemos. Julgamento: 3 de maio de 2011.

BRASIL, Tribunal Regional da $9^{a}$ Região. Processo no 04068-2015-651-09-00-5-ACO-073822017. Relatora: Thereza Cristina Gosdal. Julgamento: 7 de março de 2017.

BRASIL, Tribunal Regional da $9^{a}$ Região. Processo no 05745-2011-024-09-00-7-ACO-344002012. Relator: Ubirajara Carlos Mendes. Julgamento: 3 de agosto de 2012

BRASIL, Tribunal Regional da $9^{a}$ Região. Processo no 09172-2014-872-09-00-2-ACO-292672016. Relator: Sergio Guimarães Sampaio. Julgamento: 23 de agosto de 2016.

BRASIL, Tribunal Regional da $9^{a}$ Região. Processo no 12202-2006-012-09-00-9-ACO-190142009. Relator: Ubirajara Carlos Mendes. Julgamento: 19 de junho de 2009.

BRASIL, Tribunal Regional da $9^{a}$ Região. Processo no 40096-2009-010-09-00-3-ACO-079462014. Relator: Ubirajara Carlos Mendes. Julgamento: 14 de março de 2014.

BRASIL, Tribunal Superior do Trabalho. Agravo de Instrumento em Recurso de Revista $\mathbf{n}^{\circ}$ 1461-48.2010.5.10.0003. Relator: Alexandre Agra Belmonte. Julgamento: 25 de fevereiro de 2015.

BRASIL, Tribunal Superior do Trabalho. Recurso de Revista $\mathbf{n}^{\mathbf{0}}$ 1060-91.2010.5.02.0255. Relator: Maurício Godinho Delgado. 3a Turma. Publicado: 24 de maio de 2014.

BRASIL, Tribunal Superior do Trabalho. Recurso de Revista $\mathbf{n}^{\mathbf{0}}$ 16400-26.2009.5.13.0022. Relator: Alberto Luiz Bresciani de Fontan Pereira. Julgamento: 24 de agosto de 2011.

BRASIL, Tribunal Superior do Trabalho. Recurso de Revista $\mathbf{n}^{\mathbf{0}}$ 60800-64.2005.5.17.0181. Relatora: Delaíde Miranda Arantes. Julgamento: 28 de novembro de 2012.

BRASIL, Tribunal Superior do Trabalho. Recurso de Revista $\mathbf{n}^{\mathbf{0}}$ 761175-81.2001.5.12.5555. Relator: Milton de Moura França. Julgamento: 10 de março de 2004

CABRAL, Isabela. Como apagar uma mensagem enviada no WhatsApp depois do tempo limite. Techtudo. 04/02/2018. Atualizado 15/03/2018. Disponível em: <https:// www.techtudo.com.br/dicas-e-tutoriais/2018/02/como-apagar-uma-mensagem-enviada-nowhatsapp-depois-do-tempo-limite.ghtml>. Acesso em 20 de março de 2018.

CASILLO, João. Dano à pessoa e sua indenização. 2. ed. São Paulo: Revista dos Tribunais, 1994.

CHIOVENDA, GIUSEPPE. Instituições de Direito Processual Civil. Vol. 3, $3^{\text {a }}$ edição, Editora Bookseller, Campinas, 2002.

COSTA, Marvin. Veja como editar arquivos de áudio usando o aplicativo Gravador do iOS. TechTudo. 08/08/2013 - Atualizado em 17/03/2015. Disponível em: <http:// www.techtudo.com.br/dicas-e-tutoriais/noticia/2013/08/veja-como-editar-arquivos-de-audiousando-o-aplicativo-gravador-do-ios.html>. Acesso em 20 de março de 2018.

DALLEGRAVE NETO, José Affonso. Controvérsias sobre o dano moral Trabalhista. Revista TST, Brasília, vol. 73, no 2, abr/jun 2007. 
DIGITAL FUTURE IN FOCUS BRAZIL 2015, Relatório. Disponível em: <https:// www.comscore.com/por/Insights/Apresentacoes-e-documentos/2015/2015-Brazil-DigitalFuture-in-Focus>. Acesso em: 20 de março de 2018.

DINAMARCO, Cândido Rangel. Instituições de Direito Processual Civil. vol. III. São Paulo: Malheiros, Brasil, 2.010.

DINIZ, Maria Helena. Dicionário Jurídico. V. 2. São Paulo: Saraiva, 1998.

FARIAS, Cristiano Chaves de; BRAGA NETTO, Felipe Peixoto; ROSENVALD, Nelson. Novo tratado de responsabilidade civil. São Paulo, 2015.

FELICIANO, Guilherme Guimarães. Tese: distribuição dinâmica do ônus da prova no processo do trabalho - Critérios e casuística. Revista do Tribunal Regional do Trabalho da $15^{\mathbf{a}}$ Região, n. 32, 2008.

FERRAZ, Miriam Olivia Knopik; MIKOS, Nádia Regina de Carvalho. Reforma trabalhista e o dano moral: a dimensão ética das relações de trabalho. Livro Reformas Legislativas de um Estado em crise. Organização: Amanda Luiza Oliveira Pinto, Bárbara Mendonça Bertotti e Miriam Olivia Knopik Ferraz. Editora Ítala, Curitiba, 2018.

GARIMELLA, Kiran; TYSON, Gareth. WhatsApp, Doc? A First Look at WhatsApp Public Group Data. Association for the Advancement of Artificial Intelligence (www.aaai.org). Disponível em: 〈https://github.com/gvrkiran/whatsapp-public-groups〉.

GAZETA DO POVO. WhatsApp explica por que não pode quebrar o sigilo dos usuários. STF julga ação que questiona a possibilidade de juízes de primeiro grau ordenarem o bloqueio do aplicativo. 21/11/2017. Disponível em: <http://www.gazetadopovo.com.br/ justica/whatsapp-explica-por-que-nao-pode-quebrar-o-sigilo-dos-usuarios0g80vg7d3ygramgv1y60cq2bv>. Acesso em 20 de março de 2018.

GICO JÚNIOR, Ivo Teixeira. O documento Eletrônico como meio de prova no Brasil. Novas Fronteiras do Direito na Informática e Telemática (2001). Disponível em: <http:// works.bepress.com/ivo_teixeira_gico_junior/14/>. Acesso em 20 de março de 2018.

GOSÁLVEZ, Patrícia. O WhatsApp, uma duvidosa testemunha de acusação. Dois 'hackers' espanhóis conseguem falsificar remetentes no popular serviço de mensagens instantâneas. El País. 4 de julho de 2014. Disponível em: <https://brasil.elpais.com/brasil/2014/06/ 27/tecnologia/1403886630_918603.html>. Acesso em 20 de março de 2018.

LEAL, Sheila do Rocio Cercal Santos. Contratos Eletrônicos: Validade Jurídica dos Contratos via Internet. São Paulo: Atlas, 2007.

LESSIG, L. Code: version 2.0. 2006, New York: Basic Books.

MALLET, Estevão. Direitos de personalidade e direito do trabalho. In: Revista LTr. n. 68-11, nov. 2004.

MARANHÃO, Ney. Breves considerações sobre a tutela extrapatrimonial na realidade jurídica italiana: dano moral, biológico e existencial. In: GOULART, Rodrigo Fortunato; VILLATORE, Marco Antônio César. (Coord.) Responsabilidade civil nas relações de trabalho - reflexões atuais: homenagem ao professor José Affonso Dallegrave Neto. São Paulo: LTr 2015, p. 307-318.

OLIVEIRA, Sebastião Geraldo. Indenizações por Acidente do Trabalho ou Doença Ocupacional. 6. ed. São Paulo: LTR, 2011. 
A prova do dano moral no processo do trabalho: o entendimento dos tribunais sobre a possibilidade da utilização da gravação e as novas tecnologias de comunicação

PAMPLONA FILHO, Rodolfo. O Dano Moral na Relação de Emprego. Editora LTR. São Paulo, 1998, p.117.

PINHEIRO, Patrícia Peck. Direito Digital. $3^{\text {a }}$ ed. São Paulo: Saraiva, 2009, p.171

RIBEIRO, Daniel. Como criar conversas fakes no Facebook. Techtudo. Disponível em: <http://www.techtudo.com.br/dicas-e-tutoriais/noticia/2013/06/como-criar-conversas-fakes-nofacebook.html>. Acesso em 20 de março de 2018.

SAVATIER citado por José Raffaelli Santini. Dano Moral: doutrina, jurisprudência e prática. São Paulo: Editora de Direito, 1997, p. 42; RODRIGUES, Sílvio. Direito civil. Responsabilidade Civil, 2002, p. 30.

SILVEIRA, Sérgio Amadeu da. Redes cibernéticas e tecnologias do anonimato. In: Revista Comunicação \& Sociedade. Ano 30, n. 51, p. 113-134, jan./jun. 2009.

SOUZA JÚNIOR, Antonio Umberto. SOUZA, Fabiano Coelho de; MARANHÃO, Ney; AZEVEDO NETO, Platon Teixeira de. Reforma Trabalhista e Danos extrapatrimoniais: (Lei no. 13.467/2017 e MP 808/2017). A vida por um preço. Reforma Trabalhista ponto a ponto: estudos em homenagem ao professor Luiz Eduardo Gunther. Coordenadores: José Affonso Dallegrave Neto e Ernani Kajota. São Paulo: LTr, 2018.

SOUZA, Sérgio Iglesias Nunes de. Lesão nos Contratos Eletrônicos na Sociedade da Informação. São Paulo: Saraiva, 2009.

TELLO, Diana Carolina Valencia. Estado, sociedade e novas tecnologias: compreendendo as transformações institucionais e sociais do século XXI. Curitiba: Juruá, 2015.

VALLER, Wladimir: A Reparação do Dano Moral no Direito Brasileiro. E.V. Editora Ltda, Campinas-SP, 3. ed., 1995. FILHO, Rodolfo Pamplona. O Dano Moral na Relação de Emprego. Editora LTR, São Paulo, 1998.

VALLER, Wladimir: A Reparação do Dano Moral no Direito Brasileiro. E.V. Editora Ltda, Campinas-SP, 3. ed., 1995.

WHATSFAKE, WhatsFake- recursos. Disponível em: <http://www.whatsfakeapp.com/ pt_BR/> Acesso em 20 de março de 2018.

WIKIHOW, Como Forjar um e-mail. Disponível em: <https://pt.wikihow.com/Forjar-um-EMail>. Acesso em 20 de março de 2018.

Recebido em: 9 jun. 2018.

Aceito em: 12 nov. 2018. 